\title{
Influence of Corporate Governance on Performance in Public Hospitals in Embu County, Kenya
}

\author{
Christopher J. Mutuiri Kinyua ${ }^{1}$, Lazarus K. Ngari ${ }^{2}$ \\ ${ }^{1}$ Student, Master of Arts Public Policy \& Administration, Kenyatta University, Kenya \\ ${ }^{2}$ Department of Public Policy \& Administration, Kenyatta University, Kenya
}

\begin{abstract}
Corporate governance is important to the performance of Public Hospitals (PHs) all over the world. This study investigated the Influence of Corporate Governance on Performance in PHs in Embu County, Kenya. The objective of the study was to assess how board characteristics influence performance in PHs in Embu County. The study's main problem was to assess the performance in PHs using level of customer satisfaction, level of employees' satisfaction and efficiency. Given that there is minimal research in corporate governance on management of PHs especially in Embu County, the study addressed challenges faced by management, thus helping formulate policies and strategic guidance for County Governments (CGs). The Stewardship Leadership Theory and Organizational Leadership Style were used to develop the theoretical framework on corporate governance. The information was gathered from 140 respondents using questionnaires. Quantitative data was analyzed using Descriptive Statistics whereas Qualitative data was analyzed using Content Analysis Method. The findings were then recapitulated to ascertain whether PHs have put in place policies and guidelines that conduct best practices of corporate governance. Some of the outcome were; PHs complied with the application of corporate governance but failed to implement it fully; the PHs adhered to most of the regulations and government policies but failed to fully adhere to corporate governance guidelines on board characteristics. Finally, the summary and recommendations were then prepared for policy formulation and future use in research on corporate governance on performance in PHs in Embu County, Kenya and globally.
\end{abstract}

Key Words: Corporate Governance, Board Characteristics, Public Hospitals (PHs), County Government ( $C G)$

DOI 10.35942/ ijcab.v5i4.205

\section{Cite this Article:}

Kinyua, C., \& Ngari, L. (2021). Influence of Corporate Governance on Performance in Public Hospitals in Embu County, Kenya. International Journal of Current Aspects, 5(4), 3352. https://doi.org/10.35942/ijcab.v5i4.205

\subsection{Introduction}

Cuomo, Mallin \& Zattoni (2016) corporate governance refers to when an organization and stakeholders combine the corporate policies and best practices to meet its objectives. Corporate governance has become a significant issue in the world due to its contribution to the growth of corporations in reference to scale and activities (Clarke \& Rama, 2006). Corporate governance comprises of a set of rules which assist in governing the relationship between management and stakeholders in a corporation (Akinyele \& Fasogbon, 2010). The phrase "corporate governance" stems from a Greek word, "kyberman" which means to guide or govern. In Latin, the phrase is known as "gubernare" which entails the process of decision-making and implementation. Notably, each organization adopts a different understanding and meaning of the term corporate governance. The application of the knowledge on corporate governance makes a difference in firms leading to dominance in the market. Such businesses are thus influential to the economies and social landscape elements. Shareholders trust and market value 
enormously affect the corporation but with the emergence of globalization there is greater deterrence and low degree of government control which rebounds greater need for accountability (Crane \& Matten, 2007).

Most countries in Asia, Europe and Africa have embraced corporate governance as critical strategy in managing organizations. As such, this kind of governance is not only restricted to the private sector but also an integral element in the public sector (Kuria, 2009). Organizations at both the private and Public Sector that include corporate governance acquire benefits such as improved efficiency, effectiveness and accountability (Edward \& Clough, 2005). Therefore, practices and systems found in corporate governance form the foundation of a responsive framework which is required for conveying the organization's objectives (Gachoki \& Rotich, 2013). In Africa, with the decline in economic performance, rise in unemployment, inequality, increase in poverty and worsening of national infrastructure, most countries are struggling to expand their economies and living standards (Gatamah, 2002). Indefinite internal conflicts and external aggression have made third world countries in Africa to divert proportions of their resources making the survival of various African countries at risk. Without lasting peace and security for both property and life, it is impossible for citizens, economic participants and governments to plan and implement corporate governance systems and framework to address key issues affecting various corporations and economy.

Despite the challenges faced by third world countries in Africa, some are rising and integrating corporate governance in institutional operations. A good example of a country that has successfully adopted this strategy is Nigeria. With the assistance of the Securities and Exchange Commission (SEC), corporate governance has helped in implementing various policies with regards to governance. Such policies offer directives to all companies to exercise transparency by releasing their financial proceeds on all stock market operations thus preventing insiders' abuses (Core, Holthausen \& Larcker, 1999). Countries like Ghana, Uganda, Zimbabwe and South Africa are currently introducing institutional links that promote good corporate governance through training, awareness and technical assistance. Besides, this business strategy is a primary principle in South Africa useful in the proper utilization and management of PHs. Although some countries in Africa have adopted corporate governance, given its benefits, there is a need for more countries to integrate the strategy. Moreover, there is the need to improve and streamline the existing policies in corporate governance to ensure customer satisfaction, employees' satisfaction and efficiency in PHs.

However, there is limited information on the impact of corporate governance implementation in the Public Sector in Africa as a continent (Mulili \& Wong, 2011). Corporate governance in Kenya is not thriving since hurdles like bureaucracy, management scandals, incompetence of employees are some of the highlighted obstacles in the Government of Kenya Sessional Paper No.4 of 1991. Such problems, however, contribute to the failure of State Corporations (SCs) which do not advocate for the crucial role that corporate governance plays in any sector (Gatamah, 2002). Majority of SCs in Kenya lack governance framework on the role played by various government institutions like parliament, ministries, boards and also Chief Executive Officers (C.E.Os). The lack of such a framework creates conflicts and confusion when it comes to allocation of responsibilities and resources. Promoting performance of SCs and Public Institutions (PIs) requires the development of suitable governance framework (Ochieng, 2017).

In CGs like Embu, Nakuru, Nairobi, Laikipia, Mombasa and Kilifi, public health workers are issuing their employers strike notices due to lack of requisite personal protective gears, delayed salaries, poor leadership and management. However, with the enactment of proper laws, some of these problems will be eliminated. Arworthy (1986) argues that proper management of PHs at county level can only be successful if the government puts in place administrative and 
effective measures that will ensure there is effective implementation of law. In Nairobi CG; the introduction of the devolved units in the Department of Health revealed the local health community lacked adequate preparedness to support health functions. As a consequence, local health communities suffered from lack of political goodwill, access to information, and accountability. These challenges have greatly affected the Department of Health at the County level to the verge of various PHs like Pumwani Maternity Hospital experiencing management crisis. Only when citizens are involved in exercising accountability is when the achievements of devolutions stated aims are achieved (Arworthy, 1989).

Due to devolution in the Department of Health, the health sector suffers from financial constraints particularly in CGs such as Embu and Mombasa. Most of these CGs lack guidelines on how they can raise finances that would meet the ever-growing needs. Corporate governance needs to help CGs on how they can adequately improve structural management thus positively influence their performance. The study assisted in providing solutions to some of the health management crisis faced by these CGs on strategic leadership, information disclosures, management oversight, and board characteristic. In Embu CG, the Public Sector faces discrepancies with regards to the application of corporate governance leading to lack of accountability and efficiency in the sector. Admittedly, the efficient application of principles of corporate governance reinforces good governance in the Public Sector (Rainey, 2009). Additionally, effective governance practices bring about indefinite benefits introducing a change in the governance models. Nonetheless, it is difficult to introduce this change since most governance models are embedded on institutional environment (Aoki \& Jackson, 2008). As such, such a hindrance adversely affects the performance of the PHs. Despite numerous researches on corporate governance and management, there exists limited knowledge on the influence of corporate governance in PHs. In Kenya, PHs fail to emphasize on the role of proper management and administration since there is a lack of sufficient knowledge and policy guidelines on integration of corporate governance which has led the researcher to assess the level of customer satisfaction, level of employees' satisfaction and efficiency in the study area.

\subsection{Statement of the Problem}

PHs are governed and managed differently from private sponsored hospitals because of their varying cultures and values. As such, this study concentrated on the problem associated with the performance in PHs as they do not attain similar standards with those ran by private entities. For this reason, the research project assessed the level of customer satisfaction, level of employees' satisfaction and efficiency. It was observed that for organizations to perform effectively and efficiently, there is a need to enforce close monitoring and improve accountability. Given these attributes, there is a need for PHs to adopt corporate governance as an integral component to quality performance.

The study offers knowledge on how PHs can emphasize on board characteristics to enhance their performance. Henceforth, application of the best practices of corporate governance promotes growth and good performance in PHs; enhance leadership transformation in PIs, subsequently, spurring their growth and development. Due to the general perception that PHs act as centers of employment creation, the management fails to stress on the importance of quality performance. This historical perception creates unwillingness among managers affecting the performance of these institutions thus inhibiting growth. As a result, this research project concentrated on the conceptual observation on performance in PHs. Thus, indicating the need to incorporate board characteristics to promote quality performance. The study investigated influence of corporate governance on performance in PHs in Embu County, Kenya. 


\subsection{Study Objective}

To assess how board characteristics influence performance in PHs in Embu County.

\subsection{Literature Review}

\subsection{Theoretical Framework for Corporate Governance}

Study used Stewardship Leadership Theory. Stewardship Leadership Theory was proposed and developed by Donaldson \& Davis (1991 \& 1993). The theory's tenets provide understanding on the relationship between management and ownership in a firm. Stewardship Leadership Theory is an organization theory whose developments are built on Theory Y (Davis \& Donaldson 1991; Schoorman, Davis \& Donaldson 1997). Ideally, Theory Y is a management approach that concentrates on human work motivation. Notably, the Theory Y principle was proposed by Douglas McGregor in the 1950s and later developed in the 1960s. Stewardship Leadership Theory emphasizes that "stewards are encouraged to act in the best interest of the organization's owner who are the principals" (Davis, Schoorman \& Donaldson, 1997; p. 24). The Stewardship Leadership Theory is a key pillar to corporate governance. It heavily relies on the ideas of the Organizational Leadership Style as outlined from the article by Davis, Schoorman \& Donaldson (1997). The article highlights the relationship among Stewardship Leadership Theory, Organizational Leadership Style and the Agency Leadership Theory. Eisenhardt (1989) and Jensen \& Meckling (1976) on the above mentioned article, elaborates that the firm's performance is dependent on the psychological, situational assumptions and Stewardship Leadership Theory's mechanism.

The theory advocates for stewardship as a preferred tool in presuming goal convergence between the principal and agents. The principals and agents initiate orientation works and collective behavior which benefits the owners of the organization (principals). The orientation works are most beneficial where middle managers tend to rely on the subordinates/ junior officers' steward-like behavior since it creates a situation where both the managers and the employs operate from a common goal. Due to infusing Stewardship Leadership Theory, the organization becomes a "viable, developing and successful enterprise" (Davis, Schoorman \& Donaldson, 1997; p. 25). The Stewardship Leadership Theory's principle on Organizational Leadership Style acknowledges human resource since it stresses the importance of stewards is ensuring that the firm reaches maximum productivity. Notably, to ensure that the stewards work in support for the firm, they should be trusted and given adequate freedom. Eisenhardt (1989) agrees that the Agency Leadership Theory and the Stewardship Leadership Theory differ in the sense that the Agency Leadership Theory assumes that agents in an organization cannot be trusted and need to be adequately controlled whereas Stewardship Leadership Theory emphasizes that stewards need to be trusted and given freedom. Other scholars like Davis \& colleagues (1997) feel that control can be counterproductive since it lowers the zeal and motivation of the stewards/ agents. Additionally, in firms where the managers/ principals do not control stewards, these firms record a decrease in costs and monitoring expenses.

The study conducted by Donaldson \& Davis (1991) reveal that the incorporation of stewardship in an organization has a positive effect on the boards and CEOs, subsequently, promoting good corporate performance. From the findings of the two scholars, most companies fail to incorporate the guidelines and structures of Stewardship Leadership Theory despite it yielding a positive effect and good performance. Davis et al. (1997) provides insight through the Game Theory where he stated that if either the agent or principal defects from the steward position; it will deeply affect their work relationship. To apply Stewardship Leadership Theory, this research work emphasized on managers as principals who should trust the stewards (subordinates) and give them freedom of choice. The study also incorporated the theory to 
advocate for boards/ committees to work closely in carrying out their duties when it comes to strategic guidance and direction. Nonetheless, the philosophy focuses more on the private sector companies and tends to provide little literature on applicability in PIs. Consequently, the study provided a framework on guidelines of incorporating the Stewardship Leadership Theory under corporate governance in management of boards and committees in PHs. Stewardship Leadership Theory provides information on the relationship between stewards and principals when it comes to setting goals, work orientation and collective behavior. As the theory focuses more on these three principles, there is insufficient information on the criteria of measuring the principals' and stewards' commitment, goals evaluation, work orientation and collective behavior. Therefore, the study gathered comprehensive information using the questionnaires provided and addressed the above tenets.

\subsection{Empirical Literature}

The board characteristics play a critical role when it comes to influencing the performance in PIs thus contributing to the reduction of agency's problems. Haniffa \& Hudaib (2006) emphasize that the size and the role of the board determine the effectiveness and efficiency of corporate governance and influence the organization's performance. Going by this, a large board ensures that the organization has a great range of expertise that will play an integral role in monitoring and evaluating the firm's performance (Karamanou \& Vafeas, 2005). The researcher's arguments are laid on the foundation that a well-established board ensures that the interests of the stakeholders are put into consideration. Although the United States Corporate Board 749 stipulates guidelines on the board composition as well as size, it does not provide an explanation on the relationship that exists between the board size and institutional profits (Sarhan, Ntim \& Al-Najir, 2009). Srivastava (1992) provides further insight on this matter using the Raheja's model. This model provides a platform for trade-off between the agency cost which is considered to be high and also the insider representation which is considered to be greater than agency cost. According to the model, smaller boards are considered to be less useful in non-competitive firms but more useful in competitive firms.

One of the prominent studies conducted by Yermack (1996) investigates a sample of 425 firms on board size and composition in US for a period of eight years (1984-1991). Yermack's findings reveal a constant negative association between PIs board size and their performance. Conversely, Dalton \& Dalton (2005) posit that a small board size is highly preferred since it gives room for intellectual and genuine deliberation; critical evaluation of ideas and most of its members are involved in monitoring. Consequently, these attributes contribute positively in the performance in PHs. Age is yet another key indicator of the board's performance. Ideally, young board members have a high tendency to take risks and carry out major structural changes. Notably, when compared to young board members, independent/ conservative board members have conventional business strategies which lower their performance (Jensen \& Zajac, 2004). As such, firms with oversized conservative/ independent board members are considered to be less productive and effective. With regards to age, PIs in Kenya are arguably composed of independent/ conservative board members. Given this, Gachoki \& Rotich (2013) demonstrate that due to a history of poor governance systems, about $70 \%$ of the corporate scandals focus on conflicts of interests, weak corporate governance practices, and weak supervisory and regulatory systems.

Kaniaru, S. (2020, June 8). Personal interview (Personal interview), at the county level, County Health Management Team (CHMT) was the highest management organ. The County Executive Committee Member (CECM) of health, which comprised of 25 members, chairs the CHMT. Among the 25 members of the CHMT were 1 County Chief Officers of Health $(\mathrm{CCOH})$ who is in-charge of health and medical services. Further, 2 County Directors of Health who are in- 
charge of health and medical services also form part of this committee. Besides, the committee had County Section Heads of Departments with each working in the following department: county health, administration, immunization, officer in-charge of nurses, doctors, and officer in-charge of clinical officers.

On the other hand, each Sub-County has the Sub-County Health Management Team/ Committee (SCHMC). This organ composes of 25 members i.e. Sub-County Ministry of Health Officer (SCMOHO) who functions as the chairperson. The rest comprise of Sectional Heads of Departments. Notably, the board in-charge of Embu Teaching \& Referral Hospital comprises of 7-9 members. The chair, treasurer and other members of the board are sourced from the community whereas the C.E.O (Head of Facility) is the secretary to the board. For other health facilities at the county level, each are managed by the Health Facility Management Committees (HFMCs) comprising of 7-9 members depending on the size of the PH. The chairperson and the treasurer are sourced from the community whereas the secretary is the medical officer in-charge of facility. The Public Sector in Kenya does not consider stipulate age limit when appointing Board Members of PIs and PHs. Most of the appointments done in these firms were political appointees who lacked respect for the system and had more respect to the appointer (Krause, Lewis \& Douglas, 2006). A significant number of them were more conservative/ independent in their way of doing things which negatively affected the performances in PHs. The study noted that there was little literature on guidelines that govern appointment of Board/ committee members in PHs. In reference to this, the study provided more literature after the research was carried out on guidelines that should be considered when considering the appointment of Board/ committee Members and managers in PHs.

Demographic characteristics of the board influence the performance and strategic decisions of firms (Wiersema \& Bentel, 1992). One of the demographic variables of the study was the age of board members and the study noted that there is a lack of clarity on the relationship between young and independent/ conservative board members. In reference to this, the study revealed there was a relationship between the young and independent/ conservative board members thus indicating how this variable influenced decision making and performance in PHs. In management, educational level is viewed as one of the core indicators of skills, cognitive orientation and general knowledge (Hambrick, 2007). Bantel (1993) outlines that educated board members are more likely to demand detailed information and regular financial reporting. Reports of a study conducted by Goll \& Rasheed (2005) reveal a positive and significant relationship between the educational level and rational decision- making to the success of the organization. Ireland \& Hitt (1999) agree that educational specialty influences strategic leadership and strategic change. Managers in health committees with formal education and training in sciences such as community health and nursing; management training like administrative accounting and information resource systems management, have a better understanding of health management (Gaciri, 2015). Gaciri (2015) further suggests that board members with both management and science training are at a good position to predict, anticipate and comprehend long-term changes in the firm. On the other hand, board members with only formal science training are more likely to pursue short-term goals when compared to those with both management and science training (Hambrick, 1984).

The board members' educational level and diversity play a critical role in management and the general performance in PHs. Researchers and academicians are putting more emphasis on the composition of boards forgetting that its diversity in terms of education, skills and experience that is most important. Essentially, the effectiveness of the board closely relates to its members' educational level (Grundfest, 1992). The study noted that there was a lack of requisite literature on the relationship between roles played by educational level and performance. The study 
elaborated and provided information; on the various roles played by educational level and how it influenced performance. In reference to the performance of the firm, there was a need to avoid regression and promote heterogeneity by including more female board members (Turnbull, 1997). The study integrated the Stewardship Leadership Theory to provide the foundation for corporate governance. The theoretical framework also elaborated on the relationship between stewards and principals towards setting goals, work orientation and collective behavior. In line with the Stewardship Leadership Theory, "stewards are encouraged to act in the best interest of the owners of the organization (principals)" (Davis, Schoorman \& Donaldson, 1997 p. 24). Still, incorporating Stewardship Leadership Theory in firm management promotes good performance recording a positive effect on the board and the C.E.Os (Donaldson \& Davis, 1991). As a result, Stewardship Leadership Theory is only an intermediary arm that enhances the relationship between board, managers, employees and shareholders (Davis, Schoorman \& Donaldson, 1997).

\subsection{Conceptual Framework}

The conceptual framework looked at the relationship between independent and dependent variable. The independent variables of the study were on one side while the dependent variable was on the other. The intervening variables were government policies, labor relations and access to healthcare. The conceptual framework helped to better understand the concept of corporate governance and its influence on performance of PHs. Figure 1 below presented the conceptual framework for the study.

Independent Variable

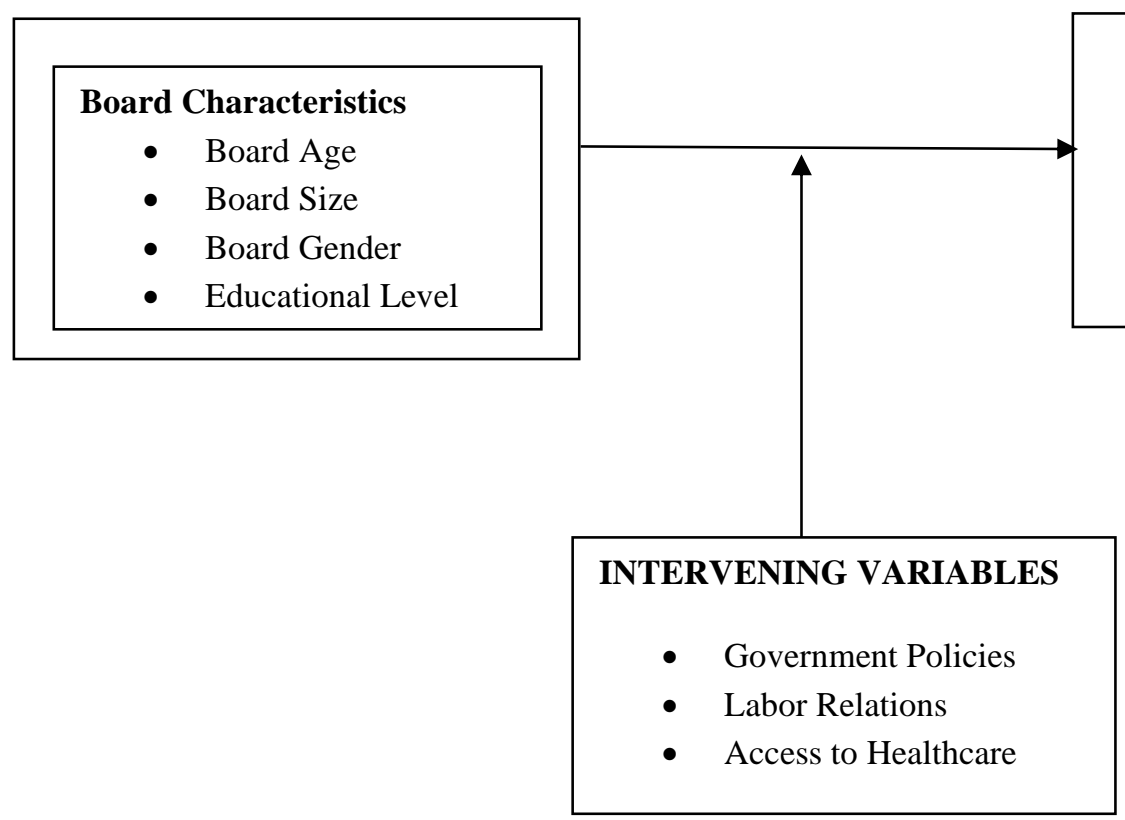

\section{Dependent Variable}

\section{PH'S PERFORMANCE}

- Level of Customer Satisfaction

- Level of Employees Satisfaction

- Efficiency

\section{Figure 1: Conceptual Framework}

Source; Author (2020)

\subsection{Research Methodology}

The study employed a descriptive design which assists in presenting the main components of the study in a logical manner to ensure that the research meets its objectives and fully addresses the research problem (Lewis, 2015). Descriptive design advocates for observance and description of prominent characteristics of the study without any influence (Creswell, 2002). 
The study incorporated the descriptive research in assessing situation at hand in terms of knowledge availability, individual(s)/ group beliefs, behavior, opinions of the public and available abilities (Kothari, Leone \& Wasley, 2005). This mode of assessing situations of the study was relevant in the case study of evaluating Influence of Corporate Governance on Performance in PHs in Embu County, Kenya.

The study was carried out in Embu County which is situated in Embu West Sub-County (Manyatta), Embu East Sub-County (Runyenjes), Mbeere South Sub-County and Mbeere North Sub-County. The target population in the study comprised of 150 health workers and 200 clients (patients admitted for at least 2 days) of PHs. The population was from four selected PHs in Embu County i.e. Embu Teaching \& Referral Hospital (Embu-West Sub-County), Siakago Level 4 Hospital (Mbeere-North Sub-County), Runyenjes Level 4 Hospital (EmbuEast Sub-County) and Kiritiri Level 3 Hospital (Mbeere-South Sub-County). A stratified random sampling was used in the study to select the respondents based on selected PHs. According to Swanborn (2010), stratified random sampling is a method used in research where target population is divided into sub-groups, latter separated sample units are selected by the researcher from each of the sample groups. The advantage of this method is that, it allows sample representation of a small group which can be compared from a large group thus reducing sampling error. In the study, based on the target population of 350, a sample of 140 was obtained using the threshold of $40 \%$ as recommended by Kothari (2004). The study used a sample size of 140 i.e. 60 health workers and 80 clients (patients admitted for at least 2 days) of PHs.

Table 1: Sample Size

\begin{tabular}{|c|c|c|c|c|c|c|c|c|}
\hline \multirow[t]{2}{*}{ Category } & \multirow{2}{*}{$\begin{array}{l}\text { Designati } \\
\text { on }\end{array}$} & \multirow[t]{2}{*}{ Freq. } & \multirow{2}{*}{$\begin{array}{l}\text { Percen } \\
\text { tage }\end{array}$} & \multicolumn{4}{|c|}{ Sample size tally } & \multirow{2}{*}{$\begin{array}{l}\text { Sample } \\
\text { size }\end{array}$} \\
\hline & & & & $\begin{array}{l}\text { Embu } \\
\text { Teaching } \\
\text { \& Referral } \\
\text { Hospital }\end{array}$ & $\begin{array}{l}\text { Runyenjes } \\
\text { Level } 4 \\
\text { Hospital }\end{array}$ & $\begin{array}{l}\text { Siakago } \\
\text { Level } 4 \\
\text { Hospital }\end{array}$ & $\begin{array}{l}\text { Kiritiri } \\
\text { Level } 3 \\
\text { Hospital }\end{array}$ & \\
\hline \multirow{5}{*}{$\begin{array}{l}\text { PHs } \\
\text { Health } \\
\text { Workers }\end{array}$} & $\begin{array}{l}\text { Nurses-in- } \\
\text { Charge }\end{array}$ & 4 & 1.14 & 1 & 1 & 1 & 1 & 4 \\
\hline & $\begin{array}{l}\text { Ordinary } \\
\text { Nurses }\end{array}$ & 69 & 19.71 & 6 & 6 & 6 & 6 & 24 \\
\hline & $\begin{array}{l}\text { Clinical } \\
\text { Officers- } \\
\text { in-charge }\end{array}$ & 4 & 1.14 & 1 & 1 & 1 & 1 & 4 \\
\hline & $\begin{array}{l}\text { Ordinary } \\
\text { Clinical } \\
\text { Officers }\end{array}$ & 69 & 19.71 & 6 & 6 & 6 & 6 & 24 \\
\hline & $\begin{array}{l}\text { PHs } \\
\text { Administr } \\
\text { ators }\end{array}$ & 4 & 1.14 & 1 & 1 & 1 & 1 & 4 \\
\hline \multicolumn{2}{|l|}{ Total } & 150 & 42.84 & & & & & 60 \\
\hline $\begin{array}{l}\text { Clients of } \\
\text { PHs }\end{array}$ & $\mathrm{N}$ & 200 & 57.16 & 20 & 20 & 20 & 20 & 80 \\
\hline $\begin{array}{l}\text { Grand } \\
\text { Total }\end{array}$ & $\mathrm{N}$ & $\underline{350}$ & $\underline{100.00}$ & & & & & $\underline{140}$ \\
\hline
\end{tabular}

Source; Author (2020)

The research instrument that was used in this study was questionnaires. The primary data in the study was collected using self-administered questionnaires meaning the data was collected from health workers and clients of PHs without the intervention of the researcher. The questionnaires were structured and semi-structured. They were both open-ended and closedended. For the open-ended questionnaires, the respondents answered questions in an open text 
format based on their knowledge, feelings and personal understanding; while the closed-ended questionnaires dealt with the questions which were narrowed down by given options. The selfadministered questionnaires enabled the respondents to fill and submit the filled questionnaires to the researcher.

The study incorporated an empirical approach meaning data was obtained through primary observation (Creswell, 2003). The primary data in the study was collected using selfadministered questionnaires meaning the data was collected from health workers and clients of PHs without the intervention of the researcher. The questionnaires were structured and semistructured. They were both open-ended and closed-ended. For the open-ended ones, the respondents answered questions in open text format based on their knowledge, feelings and personal understanding; while the closed-ended questions were narrowed down by given options. The self-administered questionnaires enabled the respondents to fill and submit the filled questionnaires to the researcher.

The use of questionnaire in the study was effective since it was easier to collect data and avoid time constraints (Kombo et al., 2006). The researcher was keen in administering the questionnaires to ensure that information from the respondents was well-captured. This was effective through proper information handling channels like register keeping for administered questionnaires. There was no need for the research to incorporate self-administered questionnaires in form of postal survey. This type of questionnaires are normally sent in form of an e-mail or even hosted on the internet platforms for example; the Web-based Computerassisted Self-interviewing/ web-CASI) for respondents to fill. However, the researcher failed to use this type of questionnaires, since all the respondents were available in person. The findings and results of the questionnaires enabled the researcher to clearly explain the meaning and purpose of each item of the study. According to a sample size of 140 respondents; staff questionnaires were filled by 60 health workers (PH Administrators, Nurses-in-Charge, Ordinary Nurses, Clinical Officers-in-Charge and Ordinary Clinical Officers) whereas clients' questionnaires were filled by 80 clients.

The data collected by the researcher was edited for any errors/ omissions to ensure accuracy of the findings. Data analysis makes data sensible and its application depends on the type of data being analyzed (qualitative or quantitative). The quantitative data in this study was analyzed using Descriptive Statistics with the assistance of Statistical Package for Social Sciences (SPSS) version 24.0. The Descriptive Statistics was in form of standard deviation, frequencies, mean scores and percentages. Qualitative data was analyzed using Content Analysis Method. The Content Analysis Method was instrumental in analyzing documented information in questionnaires. The Content Analysis Method was used to analyze content from various sources such as observations from the field and questionnaires from respondents. Experiences from health workers and the clients of PHs were analyzed using this method. The data was presented using tables and charts.

\subsection{Data Analysis Results}

\subsection{Influences of Board Characteristics on Performance in PHs in Embu County}

The researcher achieved the first objective by examining the influence of board characteristics on performance in PHs in Embu County. The information was gathered from 140 respondents i.e. 60 health workers and 80 clients. The respondents were asked on board age, board size, board gender and board educational level. 
International Journal of Current Aspects, Volume 5, Issue 4, 2021, PP 33-52, ISSN 2616-6976

[IJCAB

\subsubsection{Board Age}

Table 2: Age of HFMCs' Members Influence Performance in PHs (Health Workers)

\begin{tabular}{|l|l|l|l|l|}
\hline Likerts Scale & Freq. & Percent & Valid Percent & Cumulative Percent \\
\hline Disagree & 10 & 16.7 & 16.7 & 16.7 \\
Neither agree nor disagree & 22 & 36.7 & 36.7 & 53.3 \\
Agree & 24 & 40.0 & 40.0 & 93.3 \\
Strongly agree & 4 & 6.7 & 6.7 & 100.0 \\
Total & $\mathbf{6 0}$ & $\mathbf{1 0 0 . 0}$ & $\mathbf{1 0 0 . 0}$ & \\
\hline
\end{tabular}

Source: Field Data (2021)

Table 2: reveals that $10(16.7 \%)$ of health workers disagreed that age of Health Facility Management Committees' (HFMCs') members' influences performance in PHs, 22 (36.7\%) neither agreed nor disagreed, $24(40.0 \%)$ agreed and 4 (6.7\%) strongly agreed. This shows that the age of HFMCs' members influences performance in PHs. As per one of the respondents (health workers) at Runyenjes Level 4 Hospital, “...young HFMCs' members are good when it comes to taking management risks..."

\section{Figure 2: How Age of HFMCs' Members Influences Performance in PHs (Health Workers).}

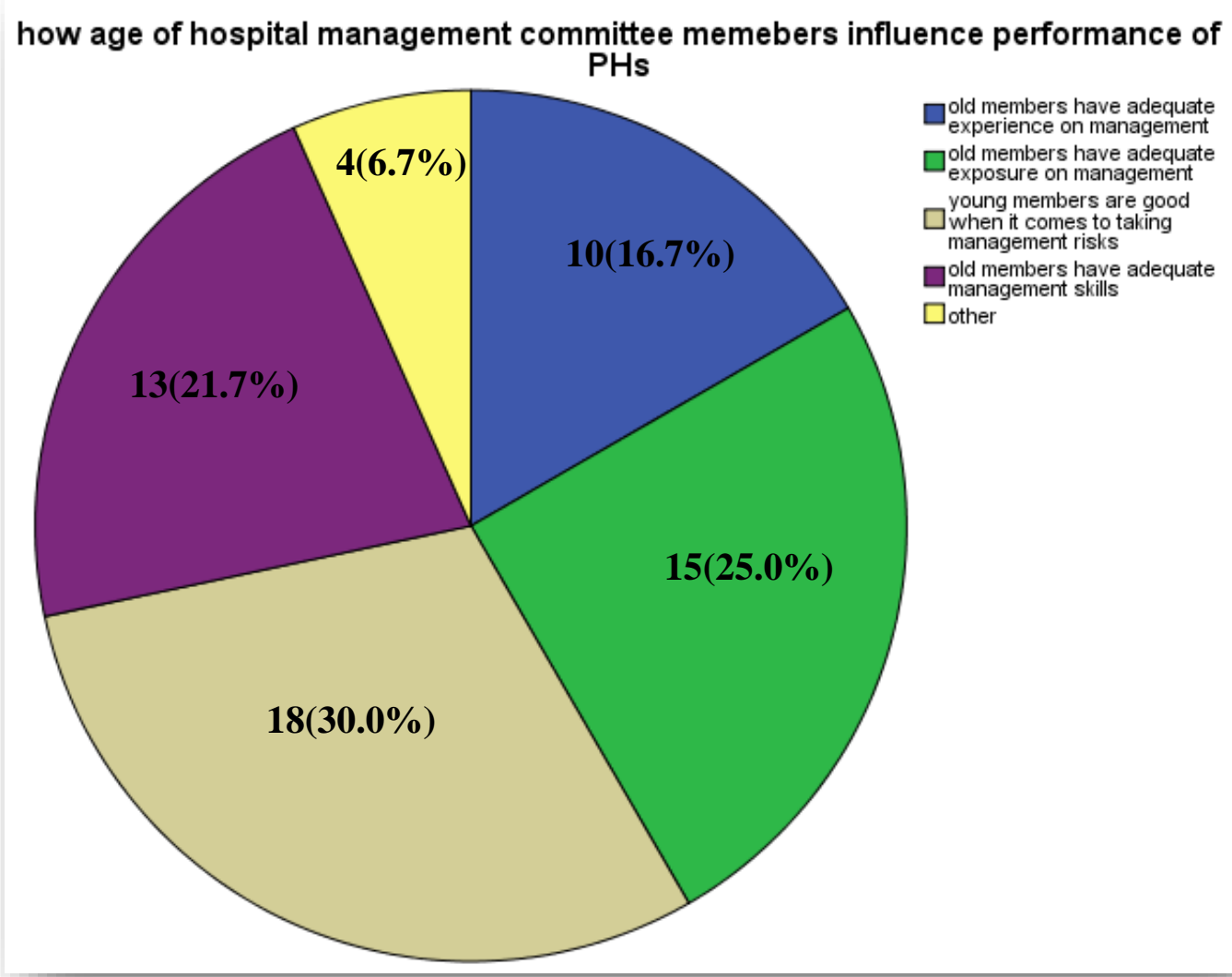

Source: Field Data (2021) 
Figure 2: revealed that $10(16.7 \%)$ of health workers felt that old HFMCs' members had adequate experience on management, 15 (25.0\%) old HFMCs' members had adequate exposure on management techniques, $18(30.0 \%)$ young HFMCs' members are good when it came to taking management risks, $13(21.7 \%)$ old HFMCs' members had adequate management skills and $4(6.7 \%)$ cited other factors. This shows there is a slight difference among responses but the dominate factor is that young HFMCs' members are good when it came to taking management risks which influences performance in PHs. According to some of the respondents (health workers) at Runyenjes Level 4 Hospital, Embu Teaching \& Referral Hospital, Kiritiri Level 3 Hospital and Siakago Level 4 Hospital, “...old HFMCs' members have adequate experience on management, old HFMCs' members have adequate exposure on management techniques, young HFMCs' members are good when it comes to taking management risks, old HFMCs' members have adequate management skills..."

Table 3: Does the Age of HFMCs' Members Influence their Performance in Service Delivery in PHs (Clients)

\begin{tabular}{|l|l|l|l|l|}
\hline Likerts scale & Freq. & \multicolumn{1}{|c|}{ Percent } & \multicolumn{1}{c|}{ Valid Percent } & \multicolumn{1}{c|}{ Cumulative Percent } \\
\hline No & 27 & 33.8 & 33.8 & 33.8 \\
Yes & 53 & 66.3 & 66.3 & 100.0 \\
Total & $\mathbf{8 0}$ & $\mathbf{1 0 0 . 0}$ & $\mathbf{1 0 0 . 0}$ & \\
\hline
\end{tabular}

Source: Field Data (2021)

Table 3: reveals that 27 (33.8\%) of clients felt that the age of HFMCs' members did not affect their performance in service delivery while $53(66.3 \%)$ felt that it affected their performance in service delivery. This meant that age influences the performance of HFMCs' members.

Figure 3: revealed that 6 (7.5\%) of clients felt that young HFMCs' members were good when it came to taking management risks which worked well for the PHs, 11 (13.8\%) felt that old HFMCs' members were skilled in management matters, 17 (21.3\%) felt that old HFMCs members had experience in management, $6(7.5 \%)$ young HFMCs' members were likely to adopt better and improved methods of service delivery, 9 (11.3\%) that young HFMCs' members had no experience in management, 2 (2.5\%) cited other factors and 29(36.1) did not answer.

As per some of the respondents (clients) at Runyenjes Level 4 Hospital, Embu Teaching \& Referral Hospital, Kiritiri Level 3 Hospital and Siakago Level 4 Hospital, “... young HFMCs' members are good when it comes to taking management risks which worked well for the PHs, old HFMCs' members are skilled in management matters, old HFMCs' members have experience in management, young HFMCs' members are likely to adopt better and improved methods of service delivery, young HFMCs' members have no experience in management..." 


\section{Figure 3: How does Age of HFMCs' Members Affect Performance in PHs (Clients)}

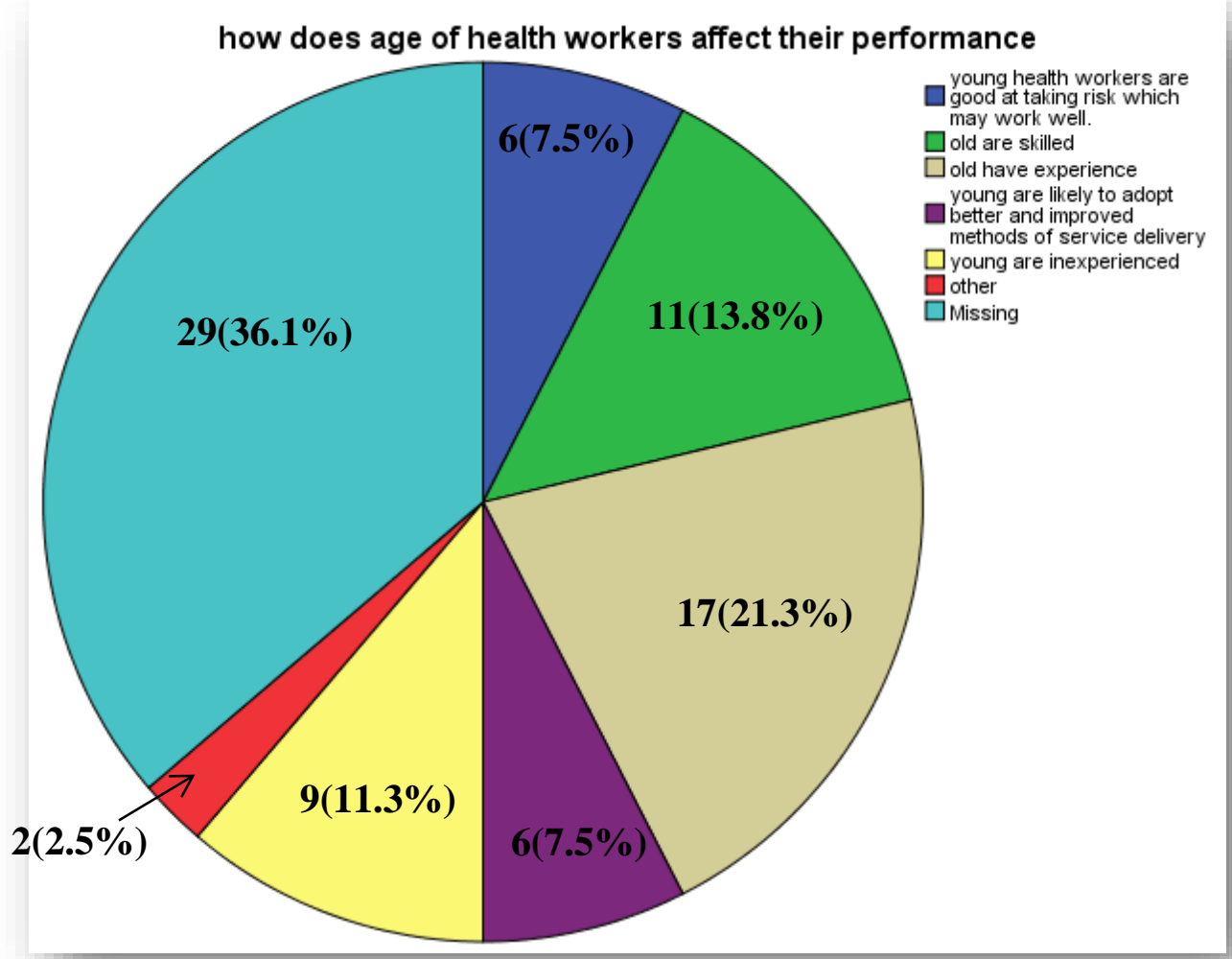

Source: Field Data (2021)

\subsubsection{Board Gender}

Table 4: HFMCs Meet the two-thirds Gender Rule (Health Workers)

\begin{tabular}{|l|l|l|l|l|}
\hline Likerts scale & Freq. & Percent & Valid Percent & Cumulative Percent \\
\hline No & 8 & 13.3 & 13.3 & 13.3 \\
Yes & 52 & 86.7 & 86.7 & 100.0 \\
Total & $\mathbf{6 0}$ & $\mathbf{1 0 0 . 0}$ & $\mathbf{1 0 0 . 0}$ & \\
\hline
\end{tabular}

Source: Field Data (2021)

Table 4: reveals that $8(13.3 \%)$ of health workers felt that HFMCs in their working station did not meet the two-thirds gender rule while $52(86.7 \%)$ felt that it met the two-thirds gender rule. This meant that a large percentage of PHs have HFMCs that meet the two-thirds gender rule which influences performance. 


\subsubsection{Board Size}

Table 5: Effectiveness of Board Size of HFMCs which Meet two-thirds Gender Rule on Performance (Health Workers).

\begin{tabular}{|l|l|l|l|l|}
\hline Likerts scale & Freq. & Percent & Valid Percent & Cumulative Percent \\
\hline Not effective at all & 7 & 11.7 & 13.2 & 13.2 \\
Effective & 38 & 63.3 & 71.7 & 84.9 \\
Other factors & 8 & 13.3 & 15.1 & 100.0 \\
Total & 53 & 88.3 & 100.0 & \\
Missing System & 7 & 11.7 & & \\
$\quad$ Total & $\mathbf{6 0}$ & $\mathbf{1 0 0 . 0}$ & & \\
\hline
\end{tabular}

Source: Field Data (2021)

Table 5: reveals that $7(11.7 \%)$ of health workers felt that HFMCs meeting two-thirds gender rule were not effective, $38(63.3 \%)$ were effective, $8(13.3 \%)$ cited other factors while 7 $(11.7 \%)$ did not answer. This meant that as far as board size is concerned, HFMCs that meet two-thirds gender rule were considered effective and influence performance.

\subsubsection{Board Educational Level}

Table 6: The Education Level of HFMCs' Members on Influence of Performance in PHs (Health Workers)

\begin{tabular}{|l|l|l|l|l|}
\hline Likerts Scale & Freq. & Percent & Valid Percent & Cumulative Percent \\
\hline Strongly disagree & 1 & 1.7 & 1.7 & 1.7 \\
Disagree & 8 & 13.3 & 13.3 & 15.0 \\
Neither agree nor disagree & 22 & 36.7 & 36.7 & 51.7 \\
Agree & 27 & 45.0 & 45.0 & 96.7 \\
Strongly agree & 2 & 3.3 & 3.3 & 100.0 \\
Total & $\mathbf{6 0}$ & $\mathbf{1 0 0 . 0}$ & $\mathbf{1 0 0 . 0}$ & \\
\hline
\end{tabular}

Source: Field Data (2021)

Table 6: reveals that $1(1.7 \%)$ of health workers strongly agreed that education level of HFMCs' members influenced performance, $8(13.3 \%)$ disagreed, $22(36.7 \%)$ neither agreed nor disagreed, $27(45.0 \%)$ agreed and $2(3.3 \%)$ strongly disagreed. This meant that the education level of HFMCs' members influences the performance in PHs. Additionally, $17(21.3 \%)$ of clients in PHs felt that the educational level of HFMCs' members did not influence performance of PHs while 63 (78.8\%) felt it influences performance thus confirming that the education level of HFMCs' members' influences performance in PHs. Further, 17 (21.3\%) of clients felt that educated HFMCs' members were skilled, 26 (32.5\%) knowledgeable, 13 $(16.3 \%)$ exposed to better methods of service delivery, $18(22.5 \%)$ did not answer while 6 $(7.5 \%)$ cited other factors. This meant that educated HFMCs' members who possess knowhow on management have a high likelihood to perform.

Some of the respondents (clients) at Runyenjes Level 4 Hospital, Embu Teaching \& Referral Hospital, Kiritiri Level 3 Hospital and Siakago Level 4 Hospital cited that, “...educated HFMCs' members are skilled and full of experience, educated HFMCs' members are knowledgeable, education exposes members of HFMCs to better methods of service delivery 
like public relations and customer handling...". This study agreed that board characteristic like board age, board size, board gender and educational level increase the firm's performance. Findings from the study revealed that $52(65.0 \%)$ of clients and $50(83.0 \%)$ of health workers agreed that board characteristics influence performance. The study findings also revealed some of the management loopholes and challenges in PHs and in the Department of Health. Such hurdles include board accountability, board professional specialization and training of health workers on public relations. Additionally, the health workers experience challenges with handling customers, incorporating vibrant communication channels, and I.S. These management loopholes and challenges, once addressed will promote customer satisfaction, employees' satisfaction and enhance PHs efficiency in service delivery.

\subsection{Conclusions and Recommendations}

\subsection{Conclusions}

PHs had developed well-structured HFMCs with a clear membership admission policy as enshrined in the constitution of Kenya. The HFMCs membership was not independent thus may have external influence. Despite the community having a representative, there was no policy framework to assess and evaluate whether their views and contributions were implemented.

\subsection{Policy Recommendations}

The study recommended that PHs adhere and implement the best corporate governance practices. Once this is done, PHs would evade superfluous disagreements with stakeholders hence reduce clients complains. Doing so would help the firm maintain a good reputation and save resources thus ensuring efficiency, effectiveness and accountability. Secondly, the study recommended that PHs incorporate the Stewardship Leadership Theory Framework. However, the adoption would only be successful and effective if it measured the main principals' (PHs management) and stewards' (junior health workers) commitment, goals evaluation, work orientation and collective behavior. The theory will go a long way in enhancing performance in PHs.

Thirdly, the study also recommended that PHs adopt an effective and efficient organizational structure that would promote reliable and quality service delivery to its clients. Notably, PHs are non-profit organizations and efficiency from the organizational structure would win the client's trust encouraging them to seek medical services, which in return, would bring wealth to PHs and Embu CG. Doing so addresses challenges like limited resources and poor infrastructure while promoting economic growth and investment stability.

Finally, the study also recommended for increased involvement of HFMCs in the investment analysis and choice opportunity. Further, best corporate governance practices should guide investment analysis and choice opportunity by delegating investment authority to functional managers who work closely with other senior managers. This investment choice would ensure that firms engage in projects/ programs that would enhance performance. More importantly, Department of Health, CHMT and SCHMC should delegate investment authority to HFMCs (with consultation and follow ups). Then, HFMCs should work closely with other senior managers in the PHs like Administrator(s), Nurse-in-Charge and Clinical Officer-in-Charge. Nonetheless, these individuals should stick to stipulated investment regulations and rules.

\subsection{Contributions to the Body of Knowledge}

Corporate governance promotes good governance which influences firm's performance through initiating sustainability and competitiveness. The spiral effects include: socioeconomic growth, public awareness and participation, skills development, board managerial 
response framework and organizational planning. PHs managers face a wide array of challenges like bureaucracy and corruption. As such, PHs managers should adopt managerial guidelines and codes which align to corporate governance best practices thus increasing the firm's survival.

\section{References}

Abugabah, A., \& Sanzogni, L. (2009). Enterprise Resource Planning Systems (ERP) and user performance: A Literature review.

Akinyele, S. T., \& Fasogbon, O.I (2010). Impact of strategic planning on organizational performance and survival. Research Journal of Business Management, 4(1), 7382.

Amin, M.E. (2005). Social Science Research: Conception methodology and Analysis: Kampla.

Anderson, R.C., \& Reeb, D.M. (2003). Founding-family ownership and firm performance: evidence from the S\&P 500. The Journal of Finance, 58(3), 1301-1328.

Andrea Bonimea-Blanc. (2012). The modern corporation and private property transactions. New Brunswick and London (UK) edition, NY.

Aoki, M., \& Jackson, G. (2008). Understanding an emergent diversity of corporate governance and organizational architecture, An essentiality based analysis. Industrial and Corporate Change, 17(1), 1-27

Authority, C. M. (2002). Guidelines on corporate governance practices by public 16 listed companies in Kenya. Nairobi: Capital Markets Authority.

Axworthy, C. S. (1986). Corporation law as if some people mattered. U. Toronto LJ, 36, 392

Bantel, K. A. (1993). Strategic clarity in banking: Role of top management team demography. Psychological reports, 73 (3_suppl), 1187-1201.

Bassiry, G. R., \& Jones, M. (1993). Adam Smith and the ethics of contemporary capitalism. Journal of Business Ethics, 12(8), 621-627.

Bathula, H. (2008). Board characteristics and firms performance: Evidence from Zealand (Doctoral dissertation, Auckland University of Technology)

Bewley, H., Gospel, H., Peccei, R., \& Willman, P. (2003). Is it Good to Talk? Information

Disclosure and Organisational Performance in the UK Incorporating evidence submitted on the DTI discussion paper' High Performance Workplaces-Informing and Consulting Employees' (No. dp0602). Centrefor Economic Performance, LSE.

Brown, L. D., \& Caylor, M. L. (2004). Corporate governance and firms' performance. Available at SSRN 586423.

Bryman, A., \& Cramer, D. (1997). Concepts and their measurement. Quantitative Data Analysis, with SPSS for Windows.

Bryson, J. M. (1988). A strategic planning process for public and non-profit organizations. Long range planning, 21(1), 73-81.

Claessens, B. J., Van Eerde, W., Rutte, C. G., \& Roe, R. A. (2004). Planning behavior and perceived control of time at work. Journal of Organizational Behavior: The International Journal of Industrial, Occupational and Organizational Psychology and

Behavior, 25(8), 937-950.

Clarke, T., \& Rama, M. D. (Eds.). (2006). Corporate governance and globalization. SAGE Publications Limited.

Colbert, A. E., Kristof-Brown, A. L., Bradley B. H., \& Barrick, M. R. (2008). CEO transformational leadership: The role of goal importance congruence in top management team. Academy of management journal, 51(1), 81-96.

Collins, J., \& Hussey, R. (2009). Business Research. A Practical Guide for Under-and Post Graduates.

Core, J. E., Holthausen, R. W., \& Larcker, D. F. (1999). Corporate governance, chief executive officer compensation, and firm performance. Journal of financial economics, 51(3), 371-406.

Crane, A., \& Matten, D. (2007). Corporate social responsibility as a field of scholarship.

Corporate Social Responsibility, Volumes I, ii \& iii, Andrew Crane, Dirk Matten, London: Sage. 
Creswell, J. (2002). Educational research: Planning, conducting, and evaluating qualitative (p. 676). Upper Saddle River, NJ: Prentice Hall. Saddle River, NJ. Prentice Hall.

Creswell, J. W., \& Creswell, J. D. (2017). Research design: Qualitative, quantitative, and mixed methods approaches. Sage publications.

Crossland, C., \& Hambrick, D. C. (2007). How national systems differ in their constraintson corporate executives: A study of CEO effects in three countries. Strategic Management Journal, 28(8), 767-789.

Cuomo, F., Mallin, C., \& Zattoni, A. (2016). Corporate governance codes: A review and research agenda. Corporate governance: an international review, 24(3), 222-241.

Dalton, C. M., \& Dalton, D. R. (2005). Boards of directors: Utilizing empirical evidence developing practical prescriptions. British Journal of management, 16, S91-S97.

Donaldson, L. (1990). The ethereal hand: Organizational economics and management theory. Academy of management Review, 15(3), 369-381.

Donaldson, Lex, and John A. Davis. 1989. "Stewardship Theory or Agency Theory: CEOGovernance and Shareholder Returns." Australian Journal of Management 16 (1): 49-64. doi:10.1177/031289629101600103.

Donaldson, Lex, and John A. Davis. 1989. "CEO Governance and Shareholder Returns: Agency Theory or Stewardship Theory.” In . Washington, DC.

Donaldson, L., \& Lex, D. (1995). American anti-management theories of organization: A critique of paradigm proliferation (Vol. 25). Cambridge University Press. Donaldson, L. (2005). For positive management theories while retaining science:
Ghoshal. Academy of Management Learning \& Education, 4(1), 109-113.

Donaldson, L. 2008. Ethics Problems and Problems with Ethics: Toward a Pro Management Theory. Journal of Business Ethics, 78: 299-311.

Donaldson, L., \& Davis, J. H. 1991. Stewardship Theory or Agency Theory: CEO governance and shareholder returns. Australian Journal of Management, 16: 49-65.

Donaldson, L., Davis, J. H. 1993. The Need for Theoretical Coherence and Intellectual Rigour in Corporate Governance Research: Reply to Critics of Donaldson and Davis. Australian Journal of Management, $\quad$ 18: 213-225.

Donaldson, W.H. (2003). Corporate governance. Business Economics, 38, 16- 20.

Davis, J. H., Schoorman, F. D., \& Donaldson, L. (2018). Toward a stewardship theory of management. In Business Ethics and Strategy (pp. 473-500). Routledge.

Davis, J. H., Schoorman, F. D., \& Donaldson, L. (1997). Davis, Schoorman, and Donaldson reply: The

distinctiveness of agency theory and stewardship theory. Academy of Management. The Academy of Management Review, 22(3), 611.

Devers, C. E., Cannella Jr, A. A., Reilly, G. P., \& Yoder, M. E. (2007). Executive compensation: A multidisciplinary review of recent developments. Journal of management, 33(6), 10161072.

Edwards, M., \& Clough, R. (2005). Corporate governance and performance. University ofCanberra, Corporate Governance ARC Project, Issues Series, paper, 1.

Electoral, I. (2012). Preliminary report on the first review relating to the delimitation of boundaries of constituencies and wards.

Eisenhardt, K. (1989). "Agency Theory: An Assessment and Review." The Academy of Management Review 14 (1): 57-74. doi:http://dx.doi.org/10.2307/258191.

Eisenhardt, K. M. (1989). Agency theory: An assessment and review. Academy of management review, 14(1), 57-74.

Fauzi, F., \& Locke, S. (2012). Board structure, ownership structure and firm $\quad$ performance: A study of New Zealand listed-firms.

Finkelstein, Sydney, Donald C, Hambrick, Albert A. \& Cannella (2006). Strategic ～leadership: Theory and research on executive, top management teams, and boards, Oxford University Press. Frydman, R., Hessel, M., \& Rapaczynski, A. (2000). Why ownership matters. Entrepreneurship and the Restructuring of Enterprises in Central Europe.CV Starr Center for Applied Economics Working

Paper, NYU, New York. 
Gachoki Sicily \& Rotich Gladys (2013). Influence of Corporate Governance on the Performance of Public Organizations in Kenya (a Case of Kenya Ports Authority) Research Journal of Finance and Accounting, Vol. 4, No.6.

Gaciri, R. M. (2015). Influence of corporate governance on performance of organizations a case of alliance capital partners limited, Nairobi, Kenya (Doctoral dissertation, University of Nairobi).

Gatamah, K. (2002). Launching Corporate Governance in Africa with an emphasis on Kenya. Washington, DC: Center for international Private Enterprise.

Galligan, D. J., \& Versteeg, M. (2013). Theoretical perspectives on the social andpolitical foundations of constitutions. Social and political foundations..., cite, 3-48.

Gerras, S. J., Clark, M., Allen, C., Keegan, T., Meinhart, R., Wong, L., ... \& Reed, G. (2010). Strategic leadership primer. ARMY WAR COLL CARLISLE BARRACKS PA.

Gillan, S., Hartzell, J. C., \& Starks, L. T. (2003). Explaining corporate governance: Boards, bylaws, and charter provisions. Weinberg center for corporate governance working paper, (2003-03).

Goll, I., \& Rasheed, A. A. (2005). The relationships between top management demographic characteristics, rational decision making, environmental munificence, performance. Organization studies, 26(7), 999-1023.

Grundfest, J. A. (1992). Just Vote no: minimalist strategy for dealing with barbarians inside the gates, Stan. L. Rev., 45, 857.

Hambrick, D. C. (2007). Upper echelons theory: An update.

Hambrick, D. C., (1984). Upper echelons: The organization as a reflection of its top managers. Academy of management review 9(2), 193-206.

Haniffa, R., \& Hudaib, M. (2006). Corporate governance structure and performance of Malaysian listed companies. Journal of business finance \& accounting, 33(7-8), 1034-1062.

Healy, P. M., \& Palepu, K. G. (2001). Information asymmetry, corporate disclosure, and the capital markets: A review of the empirical disclosure literature. Journal of accounting and economics, 31(1-3), 405-440.

Herman, R. D., \& Renz, D. O. (2008). Advancing non-profit organizational effectiveness research and theory: Nine theses. Non-profit management and leadership, 18(4), 399-415. Hutzschenreuter, T., \& Kleindienst, I. (2013). (How) Does discretion change over time? A contribution toward a dynamic view of managerial discretion. Scandinavian Journal of Management, 29(3), 264-281.

Ireland, R. D., \& Hitt, M. A. (1999). Achieving and maintaining strategic competitiveness in the 21st century: The role of strategic leadership. Academy of Management Perspectives, 13(1), 43-57.

Ireland, R. D., \& Miller, C. C. (2004). Decision-making and firm success. Academy Management Perspectives, 18(4), 8-12.

Jarrar, Y., \& Schiuma, G. (2007). Measuring performance in the public sector: challenges and trends. Measuring business excellence.

Jensen, M. C., \& Meckling, W. H. (1976). Theory of the firm: Managerial behavior, agency costs and ownership structure. Journal of financial economics, 3(4), 305-360.

Jensen, M., \& Zajac, E. J. (2004). Corporate elites and corporate strategy: How demographic preferences and structural position shape the scope of the firm. Strategic Management Journal, 25(6), 507-524.

Kaniaru, S., personal communication, June 8, 2020.

Karamanou, I., \& Vafeas, N. (2005). The association between corporate boards, audit committees, and management earnings forecasts: An empirical analysis. Journal of Accounting research, 43(3), 453-486.

Kirmi \& Minja. (2010). The relationship between strategic leadership and strategic alignment in the high-performing companies in South Africa. (Doctorate thesis) University of South Africa, Pretoria. 
Kombo, D. K., \& Tromp, D. L. (2006). Proposal and thesis writing: An introduction. Nairobi: Paulines Publications Africa, 5 (1), 814-30.

Kothari, C. R. (2004). Research methodology: Methods and techniques. New Age International.

Kothari, S. P., Leone, A. J., \& Wasley, C. E. (2005). Performance matched discretionary accrual measures. Journal of accounting and economics, 39(1), 163-197.

Krause, G. A., Lewis, D. E., \& Douglas, J. W. (2006). Political appointments, civil service systems, and bureaucratic competence: Organizational balancing and executive branch

revenue forecasts in the American states. American Journal of Political Science, 50(3), 770787.

Kuria, E. W. (2015). The Application Of Corporate Governance In The Public Sector: A Case Study Of The National Council For Law Reporting (Kenya Law) (Doctoral dissertation, United States International University-Africa).

Kyereboah-Coleman, A., \& Biekpe, N. (2006). The link between corporate governance and performance of the non-traditional export sector: evidence from Ghana. Corporate Governance: The international journal of business in society.

Lewis, S. (2015). Qualitative inquiry and research design: Choosing among five approaches. Health promotion practice, 16(4), 473-475.

Latif, L. A. (2020). HEALTH FINANCE IN KENYA'S PROGRESS TOWARDS UNIVERSAL HEALTH COVERAGE. Financing for Development, 1(2), 41-67.

Lindström, B., \& Eriksson, M. (2009). The salutogenic approach to the making of HiAP/healthy public policy: illustrated by a case study. Global health promotion, 16(1),

$17-28$.

Matengo, K., (2008). The relationship between Corporate Governance Practices and Performances, The case of banking industries in Kenya. (Unpublished MBA project)

University of Nairobi.

McDonald, M. L., \& Westphal, J. D. (2010). A little help here? Board control, CEO identification with the corporate elite, and strategic help provided to CEOs at other firms. Academy of Management Journal, 53(2), 343-370.

McGrath, R. G. (2001). Exploratory learning, innovative capacity, and managerial oversight. Academy of management journal, 44(1), 118-131.

Melese, F., Blandin, J., \& OKeefe, S. (2004). A new management model for government: Integrating activity based costing, the balanced scorecard, and total quality

management with the planning, programming and budgeting system. International

Public Management Review, 5(2), 103-131.

Mellese, D., \& Mesfin, B. (2007). Overview of environmental impact assessment in Ethiopia:

Gaps and challenges. Melca Mahiber, Addis Ababa.

Mitchell, R. K., Agle, B. R., \& Wood, D. J. (1997). Toward a theory of stakeholder identification and salience: Defining the principle of who and what really counts. Academy of management review, 22(4), 853-886.

Mugenda, O. M., \& Mugenda, A. G. (2003). Quantitative and qualitative approaches.

Mulili, B. M., \& Wong, P. (2011). Corporate governance practices in developing countries:

The case for Kenya. International journal of business administration, 2(1), 14.

Nada, K., Catarina, F., Katerina, N., Jessica, Y., Andrew, P., \& Mustafa, O., (2015). Gender

Diversity: Women's Experience and Perspectives. Human Resource Management

Journal, 54(2), 265-281.

Ochieng, J. (2017). Incorporating Principles of Corporate Governance in the Management of State Corporations in Kenya: a Critique of the 'mwongozo'Code of Governance for State Corporations (Doctoral dissertation, University of Nairobi).

Okpara, J. O. (2010). Perspectives on corporate governance challenges in a Sub Saharan African economy. Journal of business and policy research, 5(1), 110-122.

Okibo, B. W., \& Masika, E. (2014). Factors affecting monitoring of the strategic plan: A

case of Kenya Seed Company. Journal of Business and Management, 16(4), 14-20. 
International Journal of Current Aspects, Volume 5, Issue 4, 2021, PP 33-52, ISSN 2616-6976

[IJCAB

Örtenblad, A. (2004). The learning organization: towards an integrated model. The learning organization.

Organization for Economic Cooperation and Development (2004).OECDPrinciples of Corporate Governance OECD, Paris.

Oso, W. Y., \& Onen, D. (2008). A General Guide to Writing Project Proposal and Report,

a

handbook for beginning researchers.

Parkinson, J. (2003). Models of the Company and the Employment Relationship. British Journal of Industrial Relations, 41(3), 481-509.

Pound, J. (1992). Beyond takeovers: politics comes to corporate control. Harvard review, 70(2), 83-93.

Raheja, C. G. (2005). Determinants of board size and composition: A theory of corporate

boards. Journal of financial and quantitative analysis, 40(2), 283-306.

Rainey, H. G. (2009). Understanding and managing public organizations. John Wiley \& Sons.

Roberts, D. J., \& Van den Steen, E. (2000). Shareholder interests, human capital investment and corporate governance.

Roberts, J., McNulty, T., \& Stiles, P. (2005). Beyond agency conceptions of the work of the non-executive director: Creating accountability in the boardroom. British journal of management, 16, S5-S26.

Robins. (2006). Corporate governance after Sarbanes-Oxley: an Australian perspective. Corporate Governance: The International Journal of Business in Society.

Sarhan, A. A., Ntim, C. G., \& AL- Najir, B. (2009). Board diversity, corporate governance, and executive pay. International Journal of Finance \& $\quad$ Economics 24(2), 761-786

Schaltegger, S., Lüdeke-Freund, F., \& Hansen, E. G. (2011). Business cases for sustainability and the role of business model innovation: developing a conceptual framework. Centre for Sustainability Management $\quad$ (CSM), Leuphana Universität Lüneburg.

Shurttleworth.(2014). Research methods. Pearson Higher Ed

Singh, H., \& Harianto, F. (1989). Management-board relationships, takeover risk, and the adoption of golden parachutes. Academy of Management journal, 32(1), 7-24.

Solomon, J. \& Solomon, A. (2004). Corporate Governance and Accountability, Chichester the Professional Accountants in business Committee, International Good Practice Guidance.

Srivastava, V. K. (1992). CENTRALITY AND UNRETURNABLE GIFTS: SOME REFLECTIONS ON GLORIA GOODWIN RAHEJA'S" THE POISON IN THE GIFT". Cambridge Anthropology, 69-94.

Stiles, P. (2001). The impact of the board on strategy: An empirical examination. Journal of management studies, 38(5), 627-650.

Swanborn. (2010). Research design: Qualitative, quantitative, and mixed methods approaches.

Sage publications.

The Kenya National Assembly (1991).Parliamentary Sessional Paper No. 4 of 1991, Government of Kenya. Nairobi.

Terziev, V. \& Arabska (2016). The effectiveness of business management: Investment and Innovation. Univerza v Ljubljani 978-617-0. Slovenia.

Turnbull, S. (1997). Corporate governance, its scope, concerns \& theories, corporate governance. An International Review, 5(4), 180-205.

Vera, D., \& Crossan, M. (2004). Strategic leadership and organizational learning. Academy

of management review, 29(2), 222-240.

Waldman, D. A., \& Yammarino, F. J. (1999). CEO charismatic leadership: Levels-of management and levels-of-analysis effects. Academy of management review, 24(2), 266285.

Westphal, J. D., \& Fredrickson, J. W. (2001). Who directs strategic change? Director

experience, the selection of new CEOs, and change in corporate strategy. Strategic Management Journal, 22(12), 1113-1137.

Wiersema, M. F., \& Bantel, K. A. (1992). Top management team demography and corporate strategic change. Academy of Management journal, 35(1), 91-121. 
International Journal of Current Aspects, Volume 5, Issue 4, 2021, PP 33-52, ISSN 2616-6976

国 JCAB

Yermack, (1996).The Institutions of Corporate Governance. Havard Law School.

This is an open-access article published and distributed under the terms and conditions of the (c) (i) (8)

of the ${ }_{\mathrm{EY}}$ NC Creative Commons Attribution 4.0 International License of United States unless otherwise stated. Access, citation and distribution of this article is allowed with full recognition of the authors and the source. Authors seeking to publish with an Internationally Peer Reviewed Journals should consider https://www.ijcab.org/ by writing to the Editor at editor@ijcab.org or submitting online at https://journals.ijcab.org/journals/index.php. The articles must be quality and meet originality test.

IJCAB

Publishing Group 